\title{
EFEKTIFITAS METODE DEMONSTRASI DALAM MENINGKATKAN PEMBELAJARAN PUISI PADA SISWA SMA
}

\author{
Juita Tuhuloula ${ }^{1}$ dan Darwin ${ }^{2}$ \\ 1, Pendidikan Bahasa Indonesia, ${ }^{2}$ Sastra Inggris Jl. Prof. Dr. Abdurrahman Bassalamah, \\ M.Si, Namlea, Maluku \\ 1juitatuhulu@gmailcom \\ 2 darwin.r@gmail.com
}

\begin{abstract}
ABSTRAK
Penelitian ini bertujuan untuk mendeskripsikan Keefektifan metode demonstrasi dalam meningkatkan pembelajaran puisi pada siswa kelas X SMA Negeri Sawa Kecamatan Lilialy Kabupaten Buru. Penelitian ini bersifat deskriptif kuantitatif. Desain atau model yang digunakan adalah penelitian yang bersifat eksperimen, jenis preexperimental. Populasi penelitian ini adalah keseluruhan siswa kelas X SMA Negeri Sawa yang berjumlah 77 orang yang terbagi dalam tiga kelas. Sampel penelitian ini sebanyak 26 orang. Penarikan sampel dilakukan dengan cara purposif (purposif sample). Dalam penelitian ini hanya satu kelas yang dijadikan sampel. Hasil penelitian menunjukkan bahwa metode demonstrasi efektif diterapkan dalam peningkatan pembacaan puisi pada siswa kelas X SMA Negeri Sawa. Hal ini tampak pada nilai yang diperoleh siswa sebelum diberikan perlakuan yaitu 5,38 dan mengalami peningkatan setelah diberikan perlakuan berupa metode demonstrasi yaitu 7,07. Keefektifan metode ini diketahui pula berdasarkan hasil perhitungan uji t. Perbandingan hasil kemampuan pretes dan postes menunjukkan bahwa nilai t hitung sebanyak 32,05 > nilai t tabel 2,06. Sesuai hasil penelitian ini, diajukan saran sebagai berikut: (1) Guru hendaknya mempertahankan cara mengajarnya termasuk dalam memilih metode mengajar dalam pembacaan puisi yaitu metode demonstrasi sehingga, hasilnya dapat meningkat menjadi lebih baik. (2) Sekolah hendaknya melengkapi sarana pembelajaran termasuk penyediaan buku sastra, supaya minat siswa semakin termotivasi terhadap karya sastra yang ada.
\end{abstract}

\section{Kata Kunci: Metode, Puisi, Efektifitas}

\section{ABSTRACT}

This study aims to describe the effectiveness of the demonstration method in improving poetry learning in class X SMA Negeri Sawa, Lilialy District, Buru Regency. This research is descriptive quantitative. The design or model used is experimental research, pre-experimental type. The population of this study were all students of class X SMA Negeri Sawa, amounting to 77 people who were divided into three classes. The sample of this research was 26 people. Sampling was done by purposive (purposive sample). In this study only one class was sampled. The results showed that the demonstration method was effectively applied in improving poetry reading in class X SMA Negeri Sawa. This can be seen in the value obtained by students before being given treatment which is 5.38 and has increased after being given treatment in the form of a demonstration method, namely 7.07. The effectiveness of this method is also known based on the results of the t test calculation. The comparison of the results of the pretest and posttest ability 
shows that the $t$ value is 32.05> the t table value of 2.06. In accordance with the results of this study, the following suggestions are proposed: (1) Teachers should maintain their teaching methods, including in choosing teaching methods in reading poetry, namely demonstration methods so that the results can be better. (2) Schools should complete learning facilities including the provision of literary books, so that students' interest is increasingly motivated towards existing literary works.

\section{Key words : Method, Poetry, Efectuvity}

\section{PENDAHULUAN}

Pembelajaran bahasa dan sastra dimaksudkan agar siswa terdidik menjadi manusia yang berkepribadian, sopan, dan beradab, berbudi pekerti yang halus, memiliki rasa kemanusiaan, berkepedulian sosial, memiliki apresiasi budaya dan penyaluran gagasan, berimajinasi, berekspresi secara kreatif baik secara lisan maupun tertulis.

Pembelajaran Bahasa dan Sastra Indonesia juga diarahkan untuk meningkatkan kemampuan peserta didik berkomunikasi dalam berbahasa Indonesia dengan baik dan benar, baik secara lisan maupun tertulis. Bagi guru, pembelajaran bahasa Indonesia merupakan suatu tantangan tersendiri mengingat bahwa bahasa ini bagi sebagian besar sekolah di Indonesia merupakan bahasa pengantar yang dipakai untuk menyampaikan materi pelajaran yang lain.

Guru disetiap sekolah mempunyai keleluasaan untuk menentukan bahan ajar kebahasaan dan kesastraan sesuai dengan kondisi lingkungan sekolah dan kemampuan peserta didik. Pembelajaran sastra Indonesia berorientasi pada hakikat pembelajaran sastra yang menyatakan bahwa belajar sastra adalah belajar menghargai manusia dan nilai-nilai kemanusiaannya. Sastra merupakan bagian dari bahasa oleh karena itu, pembelajaran bahasa dan sastra sangatlah sulit untuk dipisahkan.

Salah satu pembelajaran sastra yang harus dibekali pada kalangan peserta didik adalah puisi. Puisi merupakan salah satu bentuk karya sastra yang berbeda dengan bentuk karya sastra lainnya. Perbedaannya antara lain terletak pada bahasanya yang jauh lebih padat dibandingkan dengan bentuk prosa dan bentuknya dibangun dalam bentuk larik-larik yang berbeda pula dengan bentuk prosa. Para pengamat karya sastra sering membedakan antara kedua bentuk puisi dan prosa dengan mengatakan bahwa puisi adalah karangan yang padat bahasanya sedangkan prosa adalah karangan yang terurai bahasanya.

Sebagai suatu bentuk karya sastra, puisi mengandung ide, gagasan, mengandung pokok persoalan tertentu yang ingin disampaikan penyair. Gagasan itu tertuang dalam keseluruhan puisi. Puisi itu sering membangkitkan semangat hidup yang menyala, dan mempertinggi rasa ketuhanan dan keimanan. Akan tetapi, seperti pada umumnya pada puisi kian kompleks dan sukar, hal ini disebabkan oleh kemajuan para penyair untuk menyajikan kemajuan seni yang setinggi-tingginya. Hal ini sesuai dengan kemajuan intelek manusia pada umumnya yang melipuiti segala bidang seni, ilmu dan kehidupan.

Fenomena yang tampak sekarang dalam pembelajaran puisi yaitu peserta didik belajar puisi hanya karena tujuan mendesak untuk memenuhi tuntutan agar dapat lulus pada ujian akhir. Dampaknya pembelajaran puisi terasa hambar bagai beban dan paksaan semata. Dan hal tersebut menyebabkan tingkat kemampuan peserta didik saat ini dalam mengapresiasi, memahami, serta menilai karya sastra puisi masih sangat mnim. Penyebab yang lain yaitu pembelajaran puisi sarat dibekali teori tetapi aplikasi dari teori tersebut masih kurang. Akhirnya ketika siswa diminta menilai sebuah puisi tidak akan tercapai dengan baik. Siswa tidak mampu memahami maksud yang disampaikan oleh pengarang dalam karya sastra puisi tersebut . 
Metode demonstrasi memiliki beberapa kelebihan di antaranya dapat meningkatkan motivasi peserta didik dalam mengapresiasi puisi, dapat membuat pembelajaran menjadi lebih jelas dan lebih konkret, sehingga menghindari verbalisme (pemahaman secara katakata atau kalimat), proses pengajaran lebih baik, dan sebagainya. Di samping memiliki kelebihan juga memiliki kekurangan di antaranya guru harus memiliki keterampilan khusus, karena tanpa ditunjang hal itu pelaksanaan demonstrasi tidak akan efektif.

Berdasarkan latar belakang yang telah dikemukakan di atas, maka permasalahan dalam penelitian ini adalah " Bagaimanakah keefektifan metode demonstrasi dalam meningkatkan pembelajaran puisi pada siswa SMA ?

\section{LANDASAN TEORI}

\section{A. Pembelajaran Sastra}

\section{Pengertian Sastra}

Kata sastra pada awalnya sebenarnya adalah kesusastraan, akan tetapi orang lebih suka menggunakan istilah sastra. Kata kesusastraan berasal dari bahasa Sangsikerta, yaitu susastradengan memperoleh imbuhan ke-an. Kata su berarti baik atau indah, dan kata sastra berarti tulisan atau karangan. Jadi, kesusastraan adalah semua tulisan atau karang yang indah dan baik, semua tulisan atau karang yang mengandung nilai-nilai kebaikan yang ditulis dengan bahasa yang indah.

Pembelajaran sastra adalah pembelajaran yang materinya berhubungan dengan sastra. Suatu hasil karya baru dapat dikatakan memeliki nilai sastra bila didalamnya terdapat kesepadanan antara bentuk dan isinya. Bentuk bahasanya baik dan indah, dan susunannya berserta isinya dapat menimbulkan perasaan haru dan kagum dihati pembacanya bentuk dan isi sastra harus saling mengisi, yaitu dapat menimbulkan kesan yang mendalam dihati para pembacanya sebagai perwujudan nilai-nilai karya seni.

a. Fungsi Sastra

a) Fingsi reaktif, yaitu fungsi atau manfaat memberikan rasa senang, gembira, dan menghibur.

b) Fungsi didaktif, yaitu fungsi atau manfaat mengarahkan dan mendidik pembaca karena mengandung nilai-nilai moral.

c) Fungsi estetika, yaitu fungsi atau manfaat yang dapat memberikan keindahan bagi pembaca karena bahasanya yang indah.

d) Fungsi moralitas, yaitu fungsi atau manfaat yang dapat membedahkan moral yang baik dan tidak baik bagi pembacanya karena sastra yang baik selalu mengandung nilai-nilai moral yang tinggi.

e) Fungsi religiusitas, yaitu fungsi atau manfaat yang mengandung ajaran-ajaran agama yang harus diteladani oleh pembaca.

b. Tujuan Pembelajaran Sastra.

Tujuan pembelajaran sastra di sekolah terbagi atas tiga yaitu :

a) Menggunakan bahasa Indonesia untuk meningkatkan kemampuan intelektual, serta kematangan emosional dan sosial.

b) Menikmati dan memanfaatkan karya sastra untuk memperluas wawasan, memperhalus budi pekerti, serta meningkatkan pengetahuan dan kemampuan berbahasa.

c) Menghargai dan membanggakan sastra Indonesia sebagai khazanah budaya dan inteltual manusia.

Pengajaran sastra membawa siswa pada ranah produktif dan apresiatif. Sastra adalah system tanda karya seni yang bermediakan bahasa. Pencitaan karya merupakan keterampilan kecerdasan intelektual dan imajinatif karya sastra untuk dibaca dan dinikmati, dimanfaatkan untuk mengembankan wawasan kehidupan. 


\section{B. Puisi}

a. Pengertian puisi

Puisi adalah salah satu bentuk kesusastraan yang tertua usianya. Puisi adalah pengkonsentrasian. Puisi ini mengonsentrasikan pada dirinya segala kesan perasaan dan pikiran dengan pengucapan yang padat. Tema atau amanat puisi itu disusun dalam baris-baris. Setiap baris bertautan atau berkorespondensi dengan baris-baris berikutnya dan membentuk satu kesatuan yang disebut bait (Nensilianti, 2003:45).

Puisi adalah sebuah hasil karya sastra seni yang tersusun dari berbagai bermacam-macam unsur dan sarana-sarana kepuitisan; puisi itu karya estetis yang bermakna, yang mempunyai arti, bukan hanya sesuatu yang kosong tanpa makna.

b. Unsur-unsur puisi

Unsur yang membangun puisi ada dua, yaitu unsur fisik dan unsur mental. Unsur fisik adalah segala unsur yang kelihatan kalau puisi dituliskan atau yang kedengaran ketika puisi dibacakan. Unsur fisik meliputi baris, bait, tipografi, dan bunyi yang tersusun dalam bentuk kata-kata. Unsur mental adalah unsur yang tidak kelihatan atau kedengaran. Unsur ini ditimbulkan oleh unsur fisik. Unsur mental ini meliputi arti atau makna, tema, asosiasi-asosiasi, citra, dan emosi.

a) Struktur fisik

Struktur fisik adalah segala unsur yang kelihatan kalau puisi ditulis atau yang kedengaran ketika puisi dibacakan. Unsur fisik itu dapat berupa diksi, gaya bahasa, versifikasi, dan tipografi.

b) Struktur Batin (Mental) Puisi

Makna atau stuktur batin yang ditimbulkan oleh sturktur fisik puisi itu biasa disebut dengan istilah hakikat puisi menurut Richard (Pradopo,2002 :41). Lebih lanjut Richard mengatakan bahwa suatu puisi mengandung suatu "makna keseluruhan" yang merupakan perpaduan dari tema (inti pokok puisi itu), perasaan (sikap penyair terhadap bahan atau objek), nada (sikap sang penyair terhadap pembaca atau penikmatnya), dan amanat (maksud atau tujuan sang penyair).

c. Jenis-jenis puisi
a) Puisi Naratif, Lirik, dan Deskriptif
b) Puisi Kamar dan Puisi Auditorium
c) Puisi Fisikal, Platonik, dan Metafisik
d) Puisi Subjektif dan Puisi Objektif
e) Puisi Konkret
f) Puisi Diafan, Gelap, dan Prismatis
g) Puisi Parnasian dan Puisi Inspiratif
h) Stansa
i)Puisi Demonstrasi dan Pampflet
j)Alegori

\section{A. Pembelajaran puisi}

Pembelajaran puisi adalah suatu proses pemberian materi dalam bentuk sebuah rangkaian tulisan yang memiliki makna konotatif, berbentuk symbol-simbol kata, serta dengan diakhiri dengan cara-cara mengapresiasi dan pengekspresian puisi dengan baik. Keberadaan pembelajaran puisi di sekolah harus diakui masih sangat minim dan kurang atratif khususnya ditingkat SMA. Kenyataan yang sering ditemui adalah siswa dalam membaca puisi masih terasa dangkal. Tidak ada penjiwaan disisi lain lemahnya pembelajaran, puisi, karena peran guru yang kurang maksimal dalam mendemontrasikan membaca puisi yang benar. Ada beberapa kemungkinan masalah yang timbul dalam pengajaran puisi adalah : Kurang adanya minat siswa terhadap 
puisi, Tidak diberikan kesempatan melihat ataupun ikut perlombaan mencipta dan membaca puisi, Guru yang kurang pandai dalam mendemonstrasikan pembacaan puisi yang menarik.

\section{METODE PENELITIAN}

Adapun jenis penilitian yang digunakan adalah jenis penilitian Pre-eksprimental penelitian ini keefektifan metode demostrasi dalam meningkatkan pembelajaran puisi dengan menggunakan 2 tes yaitu pretes dan postes.

\section{A. Desain Penelitian}

Desain adalah rancangan sebagai pedoman atau jalur dalam melakukan penelitian. Desain atau model penelitian yang digunakan dalam penelitian ini adalah desain penelitian yang bersifat eksperimen, jenis pre- eksperimental.

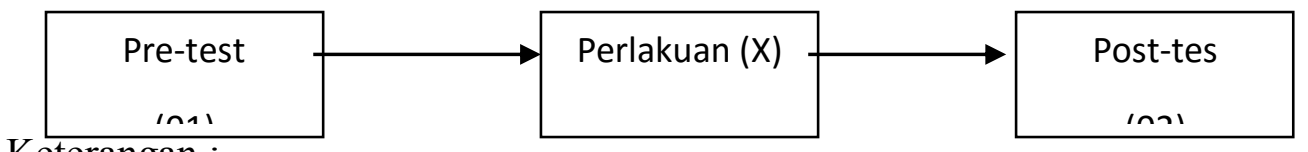

Keterangan :

01 : Tes membaca puisi sebelum (treatmen) metode demonstrasi

$\mathrm{X} \quad$ : Pemberian perlakuan pada pembelajaran membaca puisi dengan metode demonstrasi

02 : Tes membaca puisi setelah (treatment) metode demonstrasi

\section{B. Variabel Penilitian}

Penilitian ini berjudul keefektifan metode demostrasi dalam meningkatkan pembelajaran puisi pada siswa kelas X SMA Negeri Sawa Kecamatan Lilialy, Kabupaten Buru. Mencermati judul ini termasuk penilitian eksperimen semu dengan menggunakan satu variabel yaitu keefektitaf metode demostrasi dalam pembelajaran puisi.

\section{Populasi dan Sampel}

\section{Populasi}

Populasi dalam penelitian ini adalah seluruh siswa kelas X SMA Negeri Sawa Kecamatan Lilialy, Kabupaten Buru yang berjumlah 79 yang tersebar pada tiga kelas. Untuk lebih jelasnya dapat dilihat pada Tebel berikut :

Tabel 1. Jumlah Kelas dan Besarnya Populasi

\begin{tabular}{|c|c|c|c|c|}
\hline \multirow[t]{2}{*}{ No } & \multirow[t]{2}{*}{ Kelas } & \multicolumn{2}{|c|}{ Jenis kelamin } & \multirow[t]{2}{*}{ Jumlah } \\
\hline & & Laki-laki & Perempuan & \\
\hline 1 & X. a & 12 & 14 & 26 \\
\hline 2 & X. b & 12 & 14 & 26 \\
\hline 3 & X. c & 12 & 15 & 25 \\
\hline & Jumlah & 36 & 43 & 77 \\
\hline
\end{tabular}


Instrumen Penelitian yang digunakan peniliti dalam penelitian ini adalah :

1. Rencana pelaksanaan pembelajaran (RPP).

2. Indikator penilaian (Lafal, tekanan, intonasi, mimik dan penghayatan).

Untuk memperoleh data penelitian instrument yang digunakan yaitu rancangan pembelajaran dalam bentuk tes yang digunakan untuk mengukur tingkat kemampuan membaca puisi pada siswa, diberikan puisi untuk dibacakan di depan kelas dengan memperhatikan lafal, tekanan, intonasi dan mimik.

\section{Teknik Pengumpulan Data}

Untuk mendapatkan data dalam penelitian maka, diadakan pengumpulan data dengan menggunakan pre-test dan post-test yang berupa tes membaca puisi.

Adapun langkah-langkah atau prosedur pengumpulan data yang dimaksud adalah sebagai berikut :

\section{E. Teknik Analisis Data}

Data yang terkumpul dalam penelitian ini dianalisis dengan menggunakan teknik statistik deskriptif. Adapun langkah-langkah menganalisis data sebagai berikut:

Hasil penelitian berupa bahan mentah yang diperoleh dari siswa diolah dan dianalisis dengan menggunakan teknik statistik analisis ragam persentase. Langkahlangkah dalam menganalisis data sebagai berikut

a. Membuat distribusi frekuensi dan persentase nilai.

b. Mengklasifikasi kemampuan siswa sesuai dengan acuan yang dikemukakan oleh nurkancana $(2006 ; 249)$.

Tabel 2 Klasifikasi kemampuan siswa.

\begin{tabular}{|c|c|c|}
\hline No & INTERVAL (SKOR) NILAI & KATEGORI \\
\hline & & \\
1. & $85-100$ & Sangat Tinggi \\
2. & $70-84$ & Tinggi \\
3. & $56-69$ & Sedang \\
4. & $40-55$ & Rendah \\
5. & $0-39$ & Sangat Rendah \\
\hline
\end{tabular}

c. Menentukan perbandingan hasil pretes dan postes pembacaan puisi siswa dengan teknik membaca dengan menggunakan rumus :

\section{HASIL DAN PEMBAHASAN}

Berdasarkan data penelitian ini dapat diuraikan dan dideskripsikan secara rinci hasil penelitian tentang efektif tidaknya metode demonstrasi dalam meningkatkan 
pembelajaran puisi pada siswa kelas X SMA Negeri Sawa Kecamatan Lilialy, Kabupaten Buru. Untuk mengetahui keefektifan metedo tersebut terlebih dahulu perlu dianalisis tentang (1) kemampuan membaca puisi pada siswa kelas X SMA Negeri Sawa Kecamatan Lilialy, Kabupaten Buru sebelum menggunakan metode demonstrasi dan (2) kemampuan membaca puisi pada siswa kelas X SMA Negeri Sawa Kecamatan Lilialy, Kabupaten Buru setelah menggunakan metode demonstrasi. Hasil penelitian tersebut hasil kuantitatif yang dinyatakan dengan angka.

Penyajian yang bertujuan mengungkap efektif tidaknya metode demonstrasi dalam peningkatan pembacaan puisi pada siswa kelas X SMA Negeri Sawa Kecamatan Lilialy, Kabupaten Buru dapat diamati analisis berikut yang dikelompokkan ke dalam dua bagian, yaitu penyajian data pretes dan postes.

1. Penyajian Hasil Analisis Data Kemampuan Membaca Puisi siswa kelas $X$ SMA Negeri Sawa Kecamatan Lilialy, Kabupaten Buru.

Tabel 1. Daftar Skor Pretes dan Postes Kemampuan Membaca Puisi pada siswa kelas X SMA Negeri Sawa Kecamatan Lilialy, Kabupaten Buru

\begin{tabular}{|c|c|c|c|c|}
\hline $\begin{array}{c}\text { Subje } \\
\mathrm{k}\end{array}$ & Pretes & Postes & $\begin{array}{c}\text { Gain (d) Postes- } \\
\text { pretest }\end{array}$ & $\mathrm{d} 2$ \\
\hline 1 & 2 & 3 & 4 & 5 \\
\hline 1 & 40,5 & 56 & 15,5 & 240,25 \\
\hline 2 & 39,5 & 58,5 & 19 & 361 \\
\hline 3 & 47,5 & 57,5 & 10 & 100 \\
\hline 4 & 44,5 & 59,5 & 15 & 225 \\
\hline 5 & 51 & 57,5 & 6,5 & 42,25 \\
\hline 6 & 49 & 54 & 5 & 25 \\
\hline 7 & 50 & 56,5 & 6,5 & 42,25 \\
\hline 8 & 47,5 & 57 & 9,5 & 90,25 \\
\hline 9 & 49,5 & 59,5 & 10 & 100 \\
\hline 10 & 50 & 58 & 8 & 64 \\
\hline 11 & 48 & 58 & 10 & 100 \\
\hline 12 & 51,5 & 56,5 & 5 & 25 \\
\hline 13 & 48,5 & 55 & 65 & 42,25 \\
\hline 14 & 48,5 & 59 & 10,5 & 110,25 \\
\hline 15 & 49 & 55,5 & 6,5 & 42,25 \\
\hline 16 & 50,5 & 55 & 4,5 & 20,25 \\
\hline
\end{tabular}




\begin{tabular}{|c|c|c|c|c|}
\hline 17 & 48,5 & 52,5 & 4 & 16 \\
18 & 42,5 & 57 & 14,5 & 210,25 \\
19 & 49 & 56,5 & 7,5 & 56,25 \\
20 & 49,5 & 59 & 9,5 & 90,25 \\
21 & 44,5 & 54 & 9,5 & 90,25 \\
22 & 48,5 & 54 & 5,5 & 30,25 \\
23 & 47 & 53,5 & 6,5 & 42,25 \\
24. & 51 & 56 & 5 & 25 \\
25. & 51,5 & 58,5 & 7 & 49 \\
26. & 50 & 58,5 & 8,5 & 72,25 \\
\hline $\mathrm{N}=26$ & & & $\sum d=284$ & $\sum d 2=$ \\
& & & & 2311,75 \\
\hline
\end{tabular}

Berdasarkan hasil analisis data yang diuraikan, terlihat bahwa nilai kemampuan membaca puisi pada siswa kelas X SMA Negeri Sawa Kecamatan Lilialy, Kabupaten Buru dengan menggunakan metode demonstrasi sebesar 32,05. Berdasarkan nilai t hitung sebanyak 32,05 dapat dibandingkan dengan tabel nilai t (tabel terlampir) dengan $\mathrm{db}=\mathrm{N}-1=26-1=25$. Jadi, $\mathrm{db}=26-1$ dan $\mathrm{t}$ 0,975 $=2,06$ (tabel terlampir). Sementara, $\mathbf{t}$ hitung $=32,05$ dan $\mathrm{t}$ tabel $=2,06$ (signifikan 0,975\%). Dengan demikian t hitung $>\mathbf{t}$ tabel.

Hipotesis yang diuji dengan statistik uji t, yaitu Metode demonstrasi efektif diterapkan dalam meningkatkan pembelajaran puisi pada siswa kelas X SMA Negeri Sawa Kecamatan Lilialy, Kabupaten Buru (H1). Dalam penelitian ini, terungkap bahwa kemampuan membaca puisi siswa dengan menggunakan metode demonstrasi memiliki nilai yang lebih baik dibandingkan dengan nilai siswa yang tidak menggunakan metode demonstrasi.

Dalam pengujian statistik, hipotesis ini dinyatakan sebagai berikut :

$\mathrm{Ho}=\mathrm{t}$ hitung $\leq \mathrm{t}$ tabel Lawan $\mathrm{H} 1=\mathrm{t}$ hitung $\geq \mathrm{t}$ tabel

Setelah diadakan perhitungan berdasarkan hasil statistik inferensial jenis uji t desain 2 diperoleh nilai, t hitung: 32,05. krteria pengujiannya adalah Ho diterima jika $\quad \mathbf{t}$ hitung $<\mathbf{t}$ tabel dan Ho ditolak jika $\mathbf{t}$ hitung $>\mathbf{t}$ tabel. Nilai $\mathrm{t}$ tabel $=\mathrm{db}=$ $1=26-1=25$ (Angka 25 yang dilihat pada tabel). Pada taraf signifikan $0,975 \%$ diperoleh $=2,06$, ternyata $\mathbf{t}$ hitung $>\mathbf{t}$ tabel.

Berdasarkan perhitungan tersebut, maka H1 diterima dan Ho ditolak. Dengan demikian metode demonstrasi efektif diterapkan dalam peningkatan pembacaan puisi pada siswa kelas X SMA Negeri Sawa Kecamatan Lilialy, Kabupaten Buru.

\section{B. Pembahasan Hasil Penelitian}

1. Kemampuan membaca puisi dengan menggunakan metode demonstrasi

Metode demonstrasi merupakan salah satu metode dalam pembelajaran yang pelaksanannya dilakukan melalui penyajian bahan pelajaran dengan memperagakan atau mempertunjukkan kepada siswa suatu proses, situasi atau benda tertentu yang 
sedang dipelajari, baik dalam bentuk alamiah (asli) maupun dalam bentuk buatan (tiruan), yang sering disertai dengan penjelasan lisan.

Melalui metode demonstrasi, proses penerimaan siswa terhadap pelajaran akan lebih terkesan secara mendalam, sehingga membentuk pengertian yang baik dan sempurna. Djamarah (2006:102-103) menguraikan bahwa metode demonstrasi mempunyai peran, di antaranya dapat membuat pembelajaran menjadi lebih jelas dan lebih konkret, sehingga menghindari verbalisme (pemahaman secara kata-kata atau kalimat), siswa lebih mudah memahami apa yang dipelajari, proses pembelajaran lebih menarik, siswa dirangsang untuk lebih aktif mengamati, menyesuaikan antara teori dan kenyataan, dan mencoba melakukannya sendiri.

Metode demonstrasi merupakan metode yang sangat membantu siswa untuk meningkatkan daya khayal,daya pikir, sehingga sesuatu yang di ajarkan mudah dipahami dan dimengerti.dengan demikian, materi bagaimana pun bentuknya, siswa akan lebih mudah memahami jika diajarkan melalui metode demonstrasi

Berdasarkan uraian di atas, penulis termotivasi meneliti pembelajaran puisi melalui metode demostrasi. Hal ini dilakukan dengan pemahaman bahwa pembelajaran deklamasi puisi saat ini sangatlah rendah intensitasny. Padahal,aspek ini telah menjadi bagian penting dalam kurikulum yang berlaku dalam dunia pendidikan di sekolah.

Metode demonstrasi yang dipadukan dengan penemuan, memungkinkan guru membimbing anak untuk menemukan hal-hal yang baru berdasarkan praduga atau hipotesis yang disusun oleh anak. Metode demonstrasi perlu di lakukan dalam rangka pengembangan motivasi anak peserta didik karena mengingat kecendrungan anak untuk mencontoh atau meniru orang lain sebagai salah satu naluri yang sangat kuat.sifat anak tersebut sangat konstruktif dan memiliki manfaat sebab guru dapat memotivasikan anak didik untuk melakukan segi-segi yang berguna dari kehidupan,seperti bagaimana cara makan, berpakaian dan laian-lain.

2. Kemampuan membaca puisi dengan tidak menggunakan metode demostrasi (konvensional)

Proses belajar mengajar di SMA negeri sawa, khususnya siswa kelas $\mathrm{X}$ dalam pembelajaran membaca puisi belum sepenuhnya menguasai dengan baik. Kegagalan pembelajaran membaca puisi mencapai 72\% lebih.sebagai gambaran antara lain,siswa membaca puisi dengan pelafalan kata dan intonasi yang kurang tepat dan siswa yanag berani tampil secara sukarela tidak ada. Apabila hal ini tidak segera diperbaiki maka yang menjadi salah satu tujuan daru kurikulum yaitu membaca puisi dengan artikulasi yang tepat tidak akan tercapai.

Penyebaba siswa belum sepenuhnya menguasai dengan baik, ini bisa terjadi karena guru dalam mengajar hanya menggunakan metode ceramah saja.guru hanya menjelaskan apabila membaca puisi intonasinya harus benar, vokalnya harus jelas serta berekspresi yaitu sesuai dengan isi puisi yang di bacakan tanpa mendemonstrasikan secara langsung, sehingga pada saat siswa di suruh tampil tidak berani karena takut apabila tampilnya tidak baik akan ditertawakan temannya atau dimarahi guru, merasa malu sehingga pada saat membaca puisi menundukkan kepalanya, dan kurang percaya diri sehingga pada saat membaca puisi suaranya tidak bisa didengar oleh temannya yang duduk dibangku belakang serta tidak berekspresi membangkit motivasi siswa agar menyukai pembacaaan puisi dapat ditempuh dengan langkah-langkah: mengajak siswa berdiskusi tentang puisi yang 
akan dibacakan, siswa dapat melihat guru sebagai model langsung dengan kata lain dapat menggunakan metode demonstrasi.

Pemilihan metode demonstrasi merupakan tantangan bagi guru.guru akan menjadi model didepan kelas,dengan demikian guru akan berusaha meningkatkan kualitas diri. Penyajian pembelajaran yang di persiapkan dengan baik akan mendapat respondari siswanya dengan penyajian berulang-ulang dan selalu menarik akan menimbulkan motivasi siswa terhadap minat membaca puisi.

3. Perbedaan keefektifan metode demonstrasi dengan tidak menggunakan metode demonstrasi (konvensional) dalam pembelajaran membaca puisi pada siswa kelas X SMA negeri sawa

Berdasarkan hasil penyajian analisis data penelitian ini, dapat diuraikan temuan yang diperoleh dari hasil penggunaan metode demonstrasi dalam peningkatan pembacaan puisi pada siswa kelas X SMA Negeri Sawa Kecamatan Lilialy, Kabupaten Buru. Dari analisis data pretes diketahui bahwa kemampuan membaca puisi siswa dikategorikan belum memadai dengan nilai rata-rata 5,38 dan kemampuan membaca puisi siswa dikategorikan sudah memadai setelah diterapkan metode demonstrasi dengan nilai rata-rata 7,07. Hal ini menunjukkan bahwa ada peningkatan kemampuan membaca puisi siswa setelah penggunaan perlakuan dalam membaca puisi siswa kelas X SMA Negeri Sawa Kecamatan Lilialy, Kabupaten Buru. Oleh karena itu, dapat dinyatakan bahwa penggunaan perlakuan pada metode demonstrasi efektif diterapkan dan dapat meningkatkan kemampuan membaca puisi siswa kelas X SMA Negeri Sawa Kecamatan Lilialy, Kabupaten Buru.

Efektifnya metode demonstrasi dalam peningkatan pembacaan puisi siswa menurut penulis disebabkan oleh beberapa faktor. Faktor tersebut di antaranya adalah banyak perubahan proses dan hasil yang ditunjukkan oleh siswa. Pada aspek proses belajar, tampak siswa sangat antusias dan percaya diri tampil di depan kelas untuk membacakan puisi yang disediakan.

Keantusiasan dan kepercayaan diri siswa tersebut disebabkan karena siswa lebih leluasa mengapresiasikan puisi dengan gaya dia tersendiri. Sehingga berimplikasi pada hasil belajar, khususnya dalam membaca puisi yang menunjukkan banyak peningkatan.

Penggunaan perlakuan metode demonstrasi dalam membaca puisi dapat pula membantu permasalahan yang dihadapi termasuk siswa yang kurang percaya diri tampil di depan kelas untuk membacakan puisi sekarang sudah percaya diri dan yakin akan kemampuan dirinya membaca puisi.

\section{SIMPULAN}

Berdasarkan penyajian hasil analisis data dan pembahasan dapat disimpulkan tentang efektif tidaknya metode demonstrasi dalam peningkatan pembacaan puisi pada siswa kelas X SMA Negeri Sawa Kecamatan Lilialy, Kabupaten Buru.

Hasil penelitian menunjukkan bahwa kemampuan membaca puisi pada siswa kelas X SMA Negeri Sawa Kecamatan Lilialy, Kabupaten Buru sebelum penggunaan perlakuan lebih rendah dibandingkan dengan kemampuan siswa membaca puisi setelah penggunaan perlakuan. Hal ini tampak pula berdasarkan perolehan nilai rata-rata siswa sebelum penggunaan perlakuan, nilai rata-rata yang diperoleh yaitu 5,38 dan meningkat menjadi 7,07 setelah penggunaan perlakuan. 
Penggunaan perlakuan berupa metode demonstrasi efektif diterapkan dan dapat meningkatkan kemampuan membaca puisi siswa kelas X SMA Negeri Sawa Kecamatan Lilialy, Kabupaten Buru. Berdasarkan hasil perhitungan uji t desain 2 diperoleh hasil $\mathbf{t}$ hitung 32,05 > nilai $\mathbf{t}$ tabel 2,06. Hal ini menunjukkan bahwa hipotesis penelitian yang diajukam diterima.

\section{DAFTAR PUSTAKA}

Bin-Tahir, S. Z., Saidah, U., Mufidah, N., \& Bugis, R. (2018). The impact of translanguaging approach on teaching Arabic reading in a multilingual classroom. Ijaz Arabi Journal of Arabic Learning, 1(1).

Sam, B., Iye, R., Ohoibor, M., Umanailo, M. C. B., Rusdi, M., Rahman, A. B. D., \& Hajar, I. (2019). Female Feminism in the Customary Island of Buru. Int. J. Sci. Technol. Res, 8(8), 1877-1880.

Bin-Tahir, S. Z., Hanapi Hanapi, I. H., \& Suriaman, A. (2020). Avoiding Maluku Local Languages Death Through Embedded Multilingual Learning Model: Menghindari Kematian Bahasa Daerah Maluku melalui Model Pembelajaran Embedded Multilingual. Uniqbu Journal of Social Sciences, 1(1), 53-60.

Hajar, I., Salija, K., \& Muliati, A. (2019). THE INTERFERENCE OF INDONESIAN ON THE STUDENTS'ENGLISH WRITING OF MUHAMMADIYAH UNIVERSITY OF MAKASSAR (Doctoral dissertation, Doctoral dissertation, UNIVERSITAS NEGERI MAKASSAR).

Hajar, I., Ternate, K., Mukadar, S., Nirwana, A. R., \& Badu, T. K. (2020). Learning Style Of An Outstanding Student In English Learning At SMA Negeri 1 Buru:(Gaya Belajar Bahasa Inggris Siswa Berprestasi di SMA Negeri 1 Buru). Uniqbu Journal of Social Sciences, 1(2), 78-85.

Hajar, I., Rahman, A., Tenriawali, A. Y., \& Mangesa, R. (2020). THE INFLUENCE OF PODCASTS IN LEARNING ENGLISH VOCABULARY OF TWELVE GRADE STUDENTS OF SMA NEGERI 2 BURU. EXPOSURE: JURNAL PENDIDIKAN BAHASA INGGRIS, 9(2), 235-249.

Rahman, A., \& Hajar, I. (2020). The Effect of Audiobook on Reading Comprehension of the Eleventh Grade Students of SMA Negeri 2 Buru. ELT WORLDWIDE, 7(2), 104-115.

Sitompul, Hamela S., et al. "Penerapan Model Pembelajaran Sinektikuntuk Meningkatkan Hasil Belajar Peserta Didik Pada Pokok Bahasan Kologatif Larutan : (Application of Synectic Learning Models to Improve Students' Learning Achievement in Solution Colligative Discussion)." Uniqbu Journal of Exact Sciences, vol. 1, no. 2, 2020, pp. 52-58, doi:10.47323/ujes.v1i2.45. 
Tenriawali, A. Y. (2018). Representasi korban kekerasan dalam teks berita daring tribun timur: analisis wacana kritis [the representation victims of violence in tribun timur online news text: critical discourse analysis]. TOTOBUANG, $6(1), 1,15$.

Iye, R., Tenriawali, A. Y., Susiati, A., \& Buton, D. (2020). Makna dan Fungsi Emosi Mahasiswa Kota Baubau dalam Ranah Demonstrasi: The Meaning And Emotional Function Of Students Of Baubau City In The Demonstration Plan. Uniqbu Journal of Social Sciences, 1(1), 25-37.

Yusdianti, A. (2020). THE REPRESENTATION VICTIMS OF VIOLENCE IN TRIBUN TIMUR ONLINE NEWS TEXT: CRITICAL DISCOURSE ANALYSIS.

Susiati, S., Masniati, A., Tuasalamony, K., Hatuwe, R. S. M., Tahir, S. Z. B., Tenriawali, A. Y., \& Marasabessy, R. N. (2020). MEMBANGUN KETAHANAN RELEGIUS ANAK MELALUI ACTIVE PARENTAL INVOLVEMENT. Jurnal Islam Nusantara, 4(1), 111125.

Rahman, A., Atmowardoyo, H., \& Salija, K. (2018). Podcast Effects on EFL Learners' Listening Comprehension. ELT WORLDWIDE, 5(2), 151-164.

Tuharea, V. U., Bin Tahir, S. Z., Ami, I. S. O., \& Rahman, A. (2020). Buru Language Conservation Through Sustainable Mulok Learning In Buru Regency:(Konservasi Bahasa Buru melalui Pembelajaran Mulok Berkelanjutan di Kabupaten Buru). Uniqbu Journal of Social Sciences, 1(2), 49-55.

Yusuf, S., Umanailo, M. C. B., \& Nirwana, A. R. (2020). RELASI KEPALA DESA DAN BADAN PERWAKILAN DESA DALAM PEMANFAATAN DANA DESA DI KECAMATAN NAMLEA. Sosioglobal: Jurnal Pemikiran dan Penelitian Sosiologi, 4(2), 130-140.

Nirwana, A. R., \& Nirwana, A. R. (2018). Effects of Writing Corrective Feedback onStudents' Linguistic Error (Doctoral dissertation, Doctoral dissertation, UNIVERSITAS NEGERI MAKASSAR).

Mukadar, S., \& Budiono, B. (2020). Analisis Pemerataan Pendidikan Tingkat Pendidikan Dasar Di Kabupaten Buru Provinsi Maluku. Jurnal Kebijakan dan Pengembangan Pendidikan, 7(2).

Musyawir, M., \& Loilatu, S. H. (2020). Kemampuan Menulis Karangan Narasi Berdasarkan Pengalaman Pribadi Siswa:(the Ability to Write a Narrative Essay Based on Students' Personal Experiences). Uniqbu Journal of Social Sciences, 1(2), 1-12.

Loilatu, S. H., Rusdi, M., \& Musyowir, M. (2020). Penerapan Sistem Informasi Manajemen Pendidikan dalam Proses Pembelajaran. Jurnal Basicedu, 4(4), 1408-1422.

Malmia, Wa, et al. "Efektifitas Pembelajaran Contextual Teaching and Learning (Ctl) Terhadap Hasil Belajar Matematika Siswa : (the Effectiveness of Contextual Teaching and Learning (Ctl) on Student Mathematics Learning Achievements)." Uniqbu Journal of Exact Sciences, vol. 1, no. 2, 2020, pp. 31-39, doi:10.47323/ujes.v1i2.26. 
Badu, Tri K., and Muh S. Ikbal. "Perbedaan Pemahaman Konsep Fisika Siswa Melalui Model Problem-based Learning Dan Pembelajaran Interaktif: (Differences in Students' Understanding of Physics Concepts Through the Problem-based Learning Model and Concept-based Interactive Learning)." Uniqbu Journal of Exact Sciences, vol. 1, no. 2, 2020, pp. 23-30, doi:10.47323/ujes.v1i2.27.

Bin Tahir, S. Z. (2015). Multilingual behavior of Pesantren IMMIM students in Makassar. Asian EFL Journal, 86, 45-64.

Bin-Tahir, S. Z., Saidah, U., Mufidah, N., \& Bugis, R. (2018). The impact of translanguaging approach on teaching Arabic reading in a multilingual classroom. Ijaz Arabi Journal of Arabic Learning, 1(1).

Bin Tahir, S. Z. (2015). The attitude of Santri and Ustadz toward multilingual education at Pesantren. International Journal of Language and Linguistics, 3(4), 210-216.

Saidah, U., Bin-Tahir, S. Z., \& Mufidah, N. (2018). ARABIC

TEACHERS'COMPETENCE: A CASE OF MADRASAH SCHOOLS IN MALUKU. Ijaz Arabi Journal of Arabic Learning, 1(2). 